\title{
BIOFILM FORMATION, ADHESION AND MOTILITY OF BACTERIA ISOLATED FROM CHILDREN WITH URINARY TRACT INFECTIONS
}

\author{
Vodianyk A.A. ${ }^{1}$, Grechukha Y.O. ${ }^{1}$, Druzenko M.O. ${ }^{1}$, Kornijko Y.Y. ${ }^{1}$, \\ Ponyatovskiy V.A. ${ }^{1}$, Gniloskurenko A.V. ${ }^{1}$, Lavrenchuk O.V. ${ }^{2}$, \\ Bagdasarova I.V. ${ }^{2}$, Rudenko A.V. ${ }^{3}$, Mitiuriaeva-Kornijko I.O. ${ }^{1}$ \\ ${ }^{1}$ Bogomolets National Medical University, \\ 13 T.Shevchenko Blvd., Kyiv, 01601, Ukraine. \\ ${ }^{2}$ Institute of Nephrology, National Academy of Medical Sciences of Ukraine, \\ 17-B Degtyarevskaya Str., Kyiv, 04050, Ukraine. \\ ${ }^{3}$ Institute of Urology, National Academy of Medical Sciences of Ukraine, \\ 9-A V. Vinnichenko Str., Kyiv 04053, Ukraine.
}

\begin{abstract}
The purpose of this research is to determine the intensity of biofilm formation, adhesion and motility of bacteria depending on different types of children's urinary tract infections. Materials and methods: the paper contains the research of adhesion, motility and biofilm formation properties of 44 clinical isolates of bacteria from children with lower urinary tract infections, acute and chronic pyelonephritis. The ability of bacteria to form biofilms was tested using the method of microtiter plates. The motility of the microorganisms was tested using standard methods. The ability of bacteria to adhere was investigated according to Brilis, through the use of formalinized erythrocytes. Results: differences were found in the ability to form biofilm between strains of bacteria that cause infections of the lower urinary tract (optical density $0.40 \pm 0.06$ ) and chronic pyelonephritis (optical density $0.48 \pm 0.07)(p<0.05)$. Furthermore, a correlation was established between adhesion and biofilm formation abilities of bacteria $(r=0.529(p<0.01))$. It was detected that increased motility ability of the bacteria reduces the force applied by this strain to form biofilm. Conclusions: bacteria isolated from children with acute and chronic pyelonephritis showed higher ability to adhere and form biofilm than the bacteria isolated from children with lower urinary tract infection. High ability to form biofilm and adhere of the isolated bacteria can be considered an adverse predictive factor in the course of urinary tract infection.
\end{abstract}

Keywords: biofilm, adhesion, urinary tract infection, bacteria adhesion.

In recent years results from scientific studies have indicated the role biofilms play in the occurrence and development of up to $65 \%$ of nosocomial infectious diseases [1] and over $80 \%$ of all the infections of bacterial origin [2] Urinary tract infections (UTI) are among the most common infections that annually affect 150 million people worldwide [3]. UTI rank second among all pediatric infections, being outranked only by respiratory tract diseases.

Owing to their biological properties, biofilms can form on a wide range of surfaces. Urogenital tract of the human body is no exception. It was proven that biofilms can form on transitional epithelium cells, prostatic calculus and urinary catheters [4], and bacteria adhered to uroepithelium cause pyelonephritis [5]. 
Results of scientific research indicate a connection between Escherichia coli uropathogenic strains contained in biofilms and development urinary tract infections $[6,7]$, as well as a role of bacterial biofilms in development of chronic cystitis [8]. Recently, more and more data indicate a tendency of bacterial association formation by the bacteria with high adhesion index isolated from children with recurrent UTI [9]. In the recent years, there have been investigations of the different types of motility in colonization of urinary tract by uropathogenic bacteria [10].

Currently there are a limited number of publications on interrelation between different types of motility, biofilm formation and adhesive activity of bacteria, and the impact caused by these pathogenicity factors on the course of UTI.

As there are differences in severity degree of adhesion and biofilm formation factors between children and adults [11], the purpose of this research was to determine the intensity of biofilm formation, adhesion and motility of bacteria depending on different types of UTI in children.

Materials and Methods. The research was held at the Department of Pediatrics No. 4 and the Department of Microbiology, Virology and Immunology of Bogomolets National Medical University. In the course of the research, the analysis was conducted of the biological properties of 44 strains of bacteria isolated from 56 patients that were under medical treatment in Kyiv Children's clinical hospitals No. 6 and No. 7 within the period from September 2016 until January 2017. The patients were divided into three groups.

Group No. 1: 29 patients formed "Lower Urinary Tract Group". The criteria for inclusion in the group No. 1 were complaints of painful urination, dysuria, urinary urgencies, lower abdominal pains and leucocyturia at relatively unaffected overall condition of the patient.

Group No. 2: 14 patients were included in "Acute Pyelonephritis Group". The criteria for inclusion in the group No. 2 were complaints of pain in the kidney projection, increased body temperature up to low-grade fever or higher, abdominal pain, headache, dizziness, nausea, vomiting, and acute pyelonephritis characteristic changes in physical, instrumental and laboratory examination.

Group No. 3: 13 patients were included in "Chronic Pyelonephritis Recurrence Group". The criteria for inclusion in the group No. 3 were clinical signs of acute pyelonephritis and past medical history of pyelonephritis recurrence episodes.

A bacteriologic study according to Bergey's Manual of Determinative Bacteriology. with an extended antibioticogram of the urine samples of all patients were conducted at the Laboratory of Microbiology, Virology and Mycology of the State Institution "Institute of Urology of National Academy of Medical Sciences of Ukraine".

Biofilm Formation Study. The ability of bacteria to form biofilms was tested using the method of 96-well microtiter plates [12]. Sterile flat-bottomed 96-well plates (TPP-Switzerland) were filled with $200 \mu$ of 24-hour broth bacterial culture ( 0.5 according to McFarland) previously diluted with $1 \%$ glucose nutrient broth, in the proportion of 1:100. After 24 hours of incubation at $37{ }^{\circ} \mathrm{C}$ the contents of each well was evacuated, the wells were washed three times with $300 \mu \mathrm{l}$ of sterile isotonic solution. The bacteria adhered 
to the surface of plates were fixed with 60-minute exposure under a stream of hot air $\left(60^{\circ} \mathrm{C}\right)$. The wells were colored with $200 \mu \mathrm{l}$ of $1 \%$ solution of crystal violet for 15 minutes. After washing the wells 3 times with isotonic solution, the colorant was extracted with $200 \mu \mathrm{l}$ of $95 \%$ ethanol. Optical density (OD) was tested with microtiter plate reader (Humareader) of a wavelength of $630 \mathrm{~nm}$. A biofilm was considered formed if optical density index was higher than the optical density of negative control plus 3 standard deviations (Std. dev.) of negative control. Thus:

1. No biofilm: OD $<$ OD of negative control $(0.34)+3$ Std. dev. of negative control (0.02); OD < 0.4;

2. Weak biofilm $0.4<$ OD $<0.46$;

3. Medium biofilm $0.46<$ OD $<0.52$;

4. Strong biofilm OD $>0.52$.

Determination of Adhesion. Adhesion of bacteria was tested through the use of formalinized erythrocytes [13]. We used formalinized erythrocyte concentrate of a healthy donor with third rhesus-positive blood group (B(III)Rh+).

Formalinized erythrocytes were diluted in saline in the proportion of 1:20; $1 \mathrm{ml}$ of the solution was co-cultivated with $1 \mathrm{ml}$ of nutrient broth containing bacterial cells of the corresponding strain in the concentration of $109 \mathrm{cell} / \mathrm{s} / \mathrm{ml}$ during $30 \mathrm{~min}$ at $37^{\circ} \mathrm{C}$; as the vials were periodically shaken in a shaker.

After a 30-minute cultivation in the thermostat, smears were made on object-plates, and fixed with $96 \%$ solution of ethyl alcohol during 15 minutes. The smears were colored according to Romanovsky-Gimza during 30 minutes, and then adhesion of the bacteria was evaluated under a light microscope with the definition of adhesion index of the studied microorganisms (IAM). IAM average number of microbial cells in one erythrocyte involved in the adhesion.

The microorganisms were considered nonadhesive if microorganism adhesion index was less than two, moderately adhesive at IAM value from 2 to 4 , and highly adhesive at IAM higher than 4.

Determination of Motility. Identification of the different types of motility was carried out by standard methods [14]. Motility properties were determined in all clinical isolates that theoretically were able to move (Proteus mirabilis, E. coli, Pseudomonas aeruginosa). Swimming motility was determined as follows: bacteria of the researched strain were introduced through a puncture into $0.3 \%$ nutrient agar incubated in the thermostat for 24 hours at $37 .{ }^{\circ} \mathrm{C}$, and afterwards the area of motility was estimated according to the diameter of bacteria distribution area in agar.

Bacteria swarming was assessed through bacterial culture on 1\% nutrient agar, culture area not exceeding 5 millimeters in diameter. Twitching motility was studied by introducing bacteria to $0.7 \%$ nutrient agar by method of medium puncture to the bottom of Petri dish. Bacteria were incubated in the thermostat during 24 hours. After incubating, nutrient agar was removed from the surface of the dish. Having been dried in the thermostat for 30 minutes, the bottom of the dish was colored with $1 \%$ solution of crystal violet for 30 minutes. Petri dish was washed with saline and dried.

Colony growth area of less than $1 \mathrm{~cm}$ on agar indicated low swimming, swarming and twitching ability; area of 1-2 cm - as moderate ability of the indicated motility types, growth area diameter of more than $2 \mathrm{~cm}$ was considered as high motility ability. 
Swarming on a catheter was assessed by the method according to which a channel of a diameter of $1 \mathrm{~cm}$ was made in $0.9 \%$ nutrient agar. Two formed parts of nutrient agar were combined together with a part of sterile latex catheter of $1 \mathrm{~cm}$ located in the channel. Bacteria were cultured on nutrient agar in a form of a loop at the edge of a catheter and incubated for 24 hours. Bacteria growth was assessed on the opposite side of the catheter (on the other part of nutrient agar).

Analysis of the results was performed using the SPSS program version 12. The results were considered statistically significant at $\mathrm{p}<0.05$.

Results. Out of 29 patients of the first group, bacteriuria of more than $10^{3} \mathrm{CFU} / \mathrm{ml}$ was found in $12(41 \%)$ and 19 clinical strains of bacteria were isolated. Out of 14 patients of the 2 group bacteriuria of more than $10^{5} \mathrm{CFU} / \mathrm{ml}$ was found in $12(86 \%)$ and 8 strains of bacteria were isolated. In all the patients of the 3 group bacteriuria of more than $10^{4}-10^{5}$ was found and 13 strains of bacteria were isolated.

Out of the isolated bacteria E.coli prevailed - 57\% (group 1 - 52\%; group 2 - 75\%; group 3 - 54\%), Staphylococcus epidermidis - 18\% (group 1 - 19\%; group 2 - 25\%; group 3 - 12\%), Enterococcus faecalis - 11\% (group 1 - 13\%, group $2-0 \%, 3-8 \%$ ), others - 14\%. In group 1, 16\% of isolates were represented by microorganism associations which were consist of E.coli, S.epidermidis, E. faecalis, Enterobacter aerogenes. Biofilm formation of the first group patients' strains did not significantly differ and equaled as follows: E.coli $(\mathrm{n}=9)$ $0.41 \pm 0.07$ OD, S.epidermidis $(\mathrm{n}=4) 0.38 \pm 0.03 \mathrm{OD}$, E. faecalis $(\mathrm{n}=4) 0.5 \pm$ $\pm 0.1 \mathrm{OD}$. In the second group, biofilm formation index of E.coli $(\mathrm{n}=9)$ equaled $0.43 \pm 0.03 \mathrm{OD}$, which is less than of S.epidermidis $(\mathrm{n}=3) 0.52 \pm 0.1 \mathrm{OD}$ $(\mathrm{p}<0.05)$. Biofilm formation index of E.coli $(n=9)$ of the third group was at the level of $0.47 \pm 0.05$ OD (see Fig. 1).

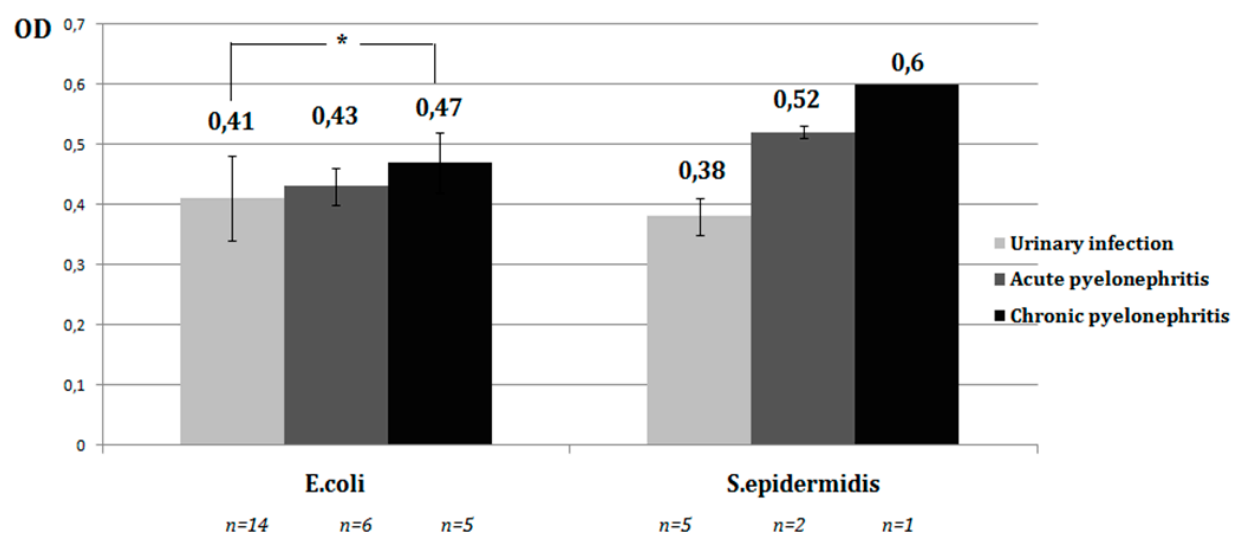

Fig.1. Intensity of biofilm formation by E.coli, S. epidermidis isolated from children with different types of UTI $(*-p<0,05)$

Among the selected pathogens only $32 \%$ did not form biofilm, mainly group 1 strains (group $1-48 \%$, group 2 - 13\%, group $3-15 \%$ ); $43 \%$ of bacteria formed weak biofilm (group $1-47 \%$, group $2-25 \%$, group $3-23 \%$ ); $14 \%$ of strains formed medium biofilm (group 1 - 4\%, group 2 - 38\%, group 3 - 38\%); 
$11 \%$ of bacteria formed strong biofilm (group $1-7 \%$, group $2-25 \%$, group $3-23 \%$ ). The results are shown in Fig. 2.

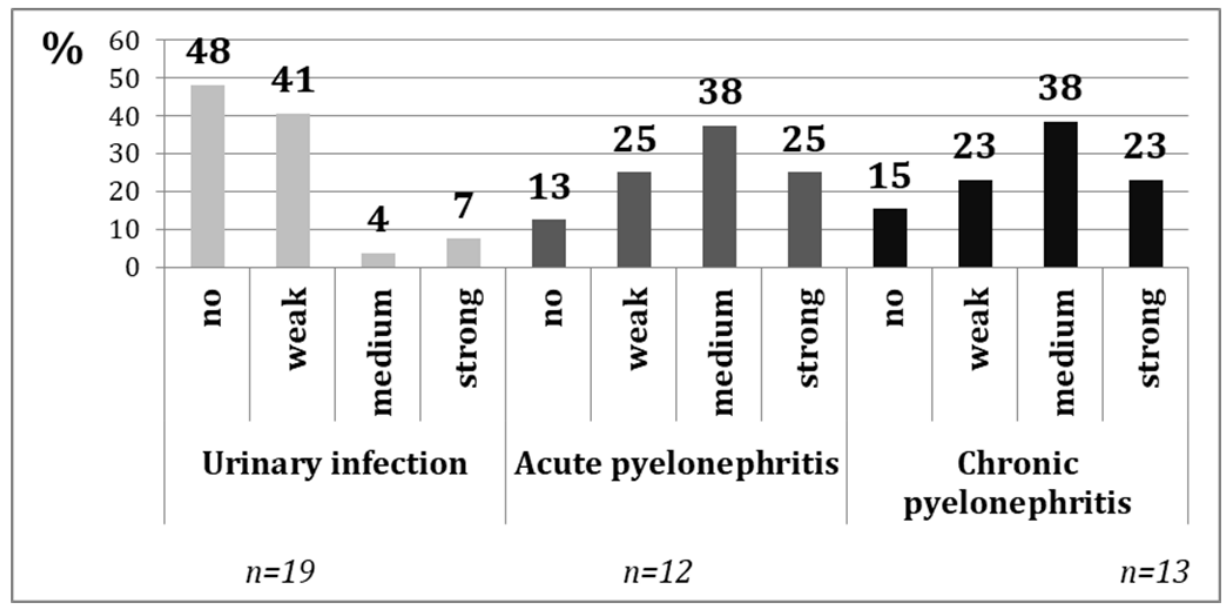

Fig. 2. Qualitative characteristic of biofilm formation by clinical strains of bacteria isolated from different types of UTI

Group 1 bacteria formed biofilm at the level of $0.40 \pm 0.06 \mathrm{OD}$, which was significantly less than group 2 bacteria formed $-0.45 \pm 0.05$ OD $(p<0,05)$ and group $3-0.48 \pm 0.07$ OD $(\mathrm{p}<0,05)$ (see Fig. 3).

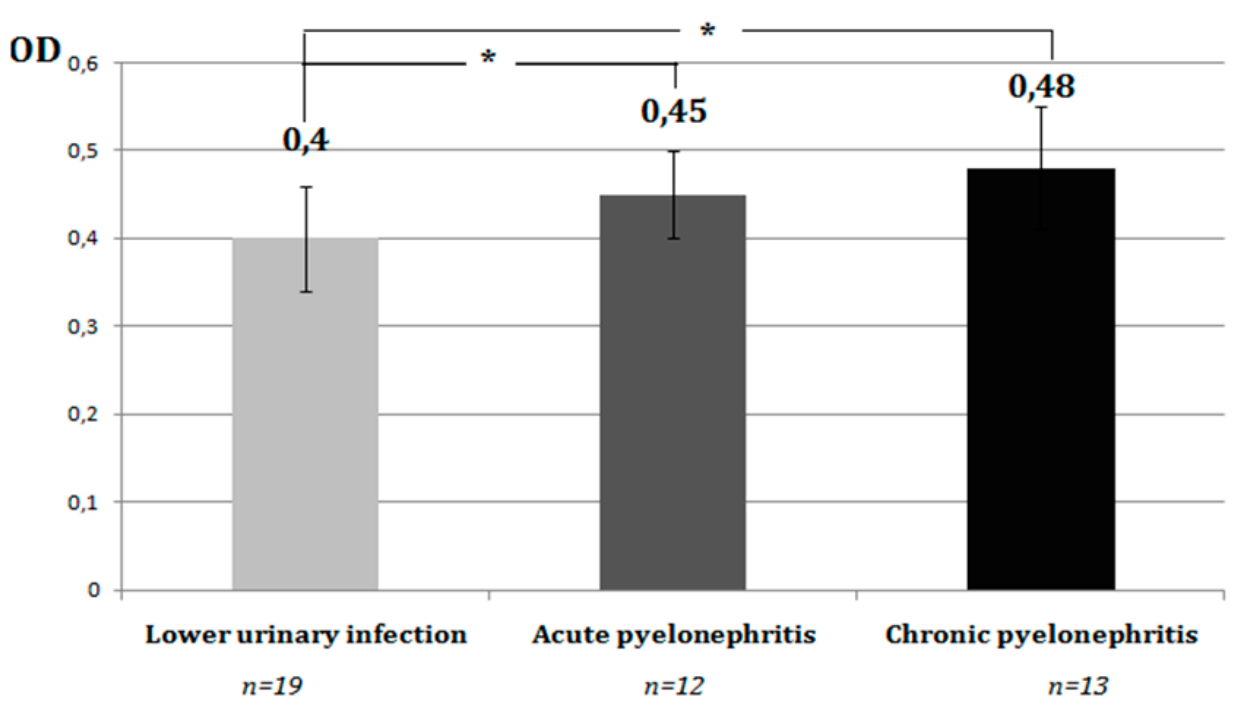

Fig. 3. Intensity of biofilm formation by the bacteria (united by the principle of clinical groups) isolated from children with different types of UTI $(*-p<0,05)$

The indices of biofilm formation by bacterial associations under cocultivation of three strains equaled $0.42 \pm 0.03 \mathrm{OD}$. When passaging on a solid nutrient medium with a subsequent counting the colonies, it was established that within the associations (E.coli, S.epidermidis, E. faecalis та E.coli, S.epidermidis, E. aerogenes) over $90 \%$ of colonies were formed with E.coli. The level of biofilm formation by the members of the association separately did not significantly differ from the level of biofilm formed in the course of their joint cultivation. 
$27 \%$ of the investigated strains did not possess adhesive properties (group $1-36 \%$, group $2-0 \%$, group $3-25 \%$ ), 39\% of bacteria possessed low adhesive ability (group $1-48 \%$, group $2-25 \%$, group $3-25 \%$ ), $22 \%$ of isolates showed medium adhesive ability (group $1-14 \%$, group $2-50 \%$, group $3-12,5 \%$ ), $12 \%$ of bacteria possessed high adhesive ability (group $1-0 \%$, group $2-25 \%$, group 3 - 37,5\%) (see Fig. 4).

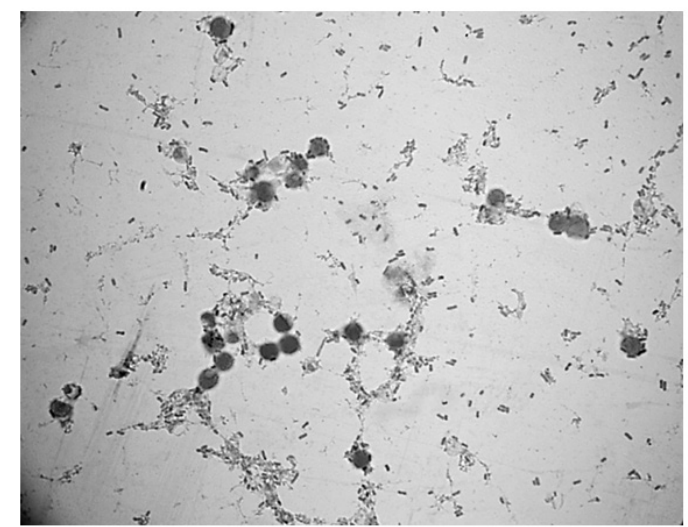

Fig. 4. Microscopy of E.coli clinical isolate adhesion to formalinized erythrocytes; coloring according to Romanovsky-Gimza (eye lens - x10, field lens - x40)

Correlation analysis carried out between the film formation and adhesion ability of bacteria showed a direct credible link $r=0.529(\mathrm{p}<0.01)$.

Out of $27(61 \%)$ investigated strains able to perform different types of motility (E. coli, Morganella morganii, P. mirabilis). $15 \%$ of the strains possessed the ability of twitching (group $1-14 \%$, group $2-20 \%$, group $3-14,5 \%$ ), 37\% had swarming ability (group $1-21 \%$, group $2-60 \%$, group $3-43 \%$ ), $22 \%$ swimming ability (group $1-7 \%$, group $2-40 \%$, group $3-43 \%$ ), no one of the studied bacteria had the ability of catheter swarming.

A credible direct correlation was established between swimming and swarming ability of the bacteria $\mathrm{r}=0.706(\mathrm{p}<0.01)$ and swimming and twitching ability $r=0.55(p<0.01)$. It was observed that increased motility of the bacteria ability of this strain to form biofilm. (see Fig. 5)
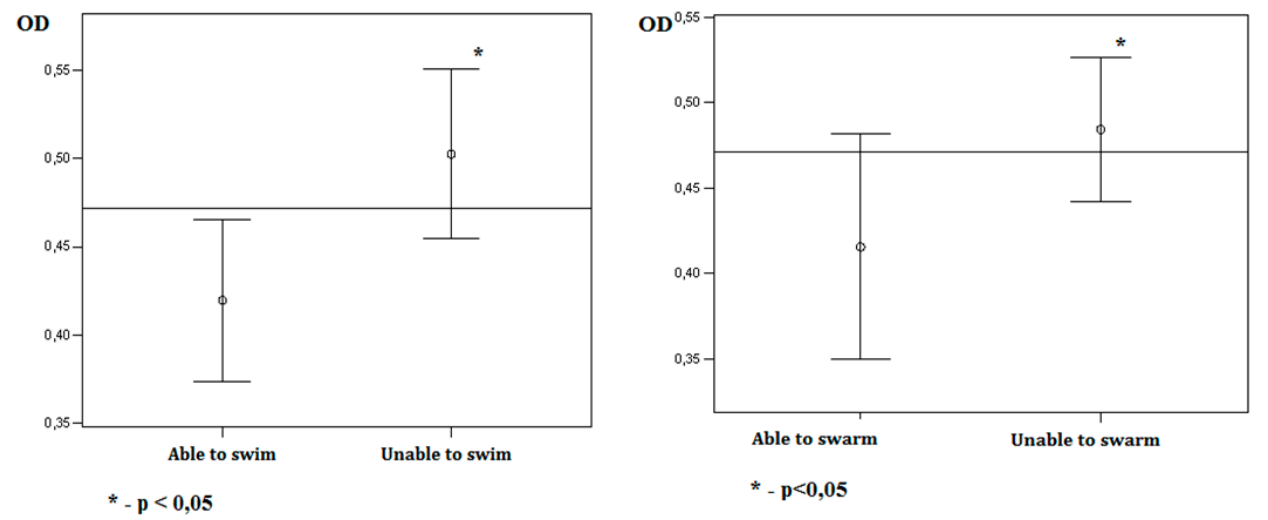

Fig. 5. The relation between the ability to different types of motility and the ability to form biofilm 
Discussions. For colonizing the urinary tract, bacteria need virulence factors that facilitate adhesion to the urothelium. Microorganism motility plays an important role in this process, as well as the ability to form biofilm in order to avoid the effects of the immune system and antibacterial factors.

The level of biofilm formation by different types of bacteria isolated from children with equal clinical forms of UTI differed insignificantly and did not demonstrate a statistically credible difference. Conversely, even bacteria of one type (E.coli, S.epidermidis) isolated from different forms of UTI possessed a statistically credible difference in ability to form biofilm. The results of the research demonstrate that bacteria isolated from lower urinary tract infections possess the lowest level of biofilm formation ability, and bacteria isolated from chronic pyelonephritis recurrence possess the highest. The received data are confirmed in other publications [15].

We have found no connection between motility ability and various forms of UTI. Perhaps migration of bacteria to the renal pelvis in children is provided not so much by the properties of the bacterium itself as by peculiarities of the macroorganism (for example, a reflux). The absence of connection between motility indices of pathogens and urinary tract colonization is demonstrated in some other researches [7].

We consider that the established correlation between adhesive ability and biofilm formation ability at the level $r=0.529(p<0.01)$ can be explained with the fact that adhesion is one of the key stages of biofilm formation. Microtiter plate method can be significantly limited by testing the ability of nonspecific adhesion of bacteria (bacteria adhere to plastic of 96-well plate). The model of adhesion determination used in the present research permits us to test nonspecific adhesive ability (bacteria adhere to glycophorin glycocalyx of the erythrocytes, which is analogical in epithelium cells), thus considering the availability of the determined correlation it can be assumed that bacteria that demonstrate high level of nonspecific adhesion possess high specific adhesion ability.

The established correlation between swimming and swarming ability of the bacteria $r=0.706(p<0.01)$ is explained by the fact that both types of motility are conditioned by the presence of flagella. It was found that the strains capable of active movement have less ability to form biofilms. A series of studies confirm a number of phenotypic differences between planktonic and biofilm (settled) forms of bacteria [16]. In the transition to a settled form of existence, bacteria alter the expression of many genes. We believe that this fact may explain the decrease of motility ability in the transition to biofilm form.

Correlations between adherence ability and biofilm formation capacity of bacteria with clinical form of the urinary tract infection has crucial meaning, because, in one side, determination of pathogenic properties of bacteria could serve as predictive tool, on the other side, it is one of the evidences that biofilm formation ability is important pathogenic factor that contributes to the development of infectious process.

Conclusions. Diverse adhesion and biofilm formation ability of bacteria was established depending on the type of UTI from which they were isolated. 
The bacteria isolated from children with acute and chronic pyelonephritis possess higher level of adhesion and biofilm formation ability than the bacteria isolated from children with lower urinary tract infection.

Adhesive ability of the bacteria correlates with their biofilm formation ability, whereas we have established no dependencies between microorganism motility and biofilm formation ability or UTI type.

High level of biofilm formation and adhesion ability of the isolated bacteria can be considered an adverse predictive factor in the course of UTI.

\title{
ЗДАТНІСТЬ ДО ФОРМУВАННЯ БІОПЛІВОК, АДГЕЗІЇ ТА РУХЛИВОСТІ У БАКТЕРІЙ, ВИДІЛЕНИХ ВІД ДІТЕЙ 3 ІНФЕКЦІЮЮ СЕЧОВИХ ШЛЯХІВ
}

\author{
Водяник А.А. ${ }^{1}$, Гречуха С.О. ${ }^{1}$, Друзенко М.Г. ${ }^{1}$, Корнійко С.Н. ${ }^{1}$, \\ Понятовський В.А. ${ }^{1}$, Гнилоскуренко Г.В. ${ }^{1}$, Лавренчук О.В. ${ }^{2}$, \\ Багдасарова I.В. ${ }^{2}$, Руденко А.В. ${ }^{3}$, Мітюряева-Корнійко I.O. ${ }^{1}$ \\ ${ }^{1}$ Національний медичний університет ім. О.О.Богомольия, \\ бул.Т.Шевченка, 17, Київ, 01601, Україна \\ ${ }^{2}$ Інститут нефрології НАМН України, \\ вул. Дегтярівська, 17-В, Київ, 04050, Украӥна \\ ${ }^{3}$ Інститут урології НАМН України, \\ вул. В.Винниченка, 9-А, Київ, 04053, Україна
}

Резюме

Метою даного дослідження було визначення інтенсивності біоплівкоутворення, адгезивної здатності бактерій, їх рухливості в залежності від різних видів інфекцій сечових шляхів у дітей. Матеріали і методи: у роботі досліджено здатність до адгезії, рухливості та біоплівкоутворення у 44 клінічних ізолятів бактерій, що були виділені від дітей, хворих на інфекцію нижніх сечових шляхів, гострий та хронічний пієлонефрит. Здатність бактерій до формування біоплівки була перевірена за допомогою методу 96-лункових мікротитрувальних планшетів. Рухливість мікроорганізмів визначалася стандартними методиками. Здатність бактерій до адгезії була досліджена за методикою Бріліса з використанням формалінізованих еритроцитів. Результати: було встановлено відмінності у здатності формувати біоплівку між штамами бактерій, які викликають інфекцію нижніх сечових шляхів $(0,40 \pm 0,06$ ОЩ) та хронічний пієлонефрит $(0,48 \pm 0,07$ ОЩ) ( $<0,05)$. Також була встановлена кореляція між адгезивною здатністю бактерій та здатністю до утворення біоплівки ( $\mathrm{r}=0,529$ $(\mathrm{p}<0,01))$. Було встановлено, що бактерії, які здатні до руху, мали меншу здатність до формування біоплівки. Висновки: здатність до адгезії та формування біоплівки більша у бактерій, які були виділені від дітей з гострим та хронічним пієлонефритом, ніж від дітей з інфекцією нижніх сечових шляхів.

Висока здатність до формування біоплівки та адгезії у ізольованих бактерій може вважатися несприятливим прогностичним фактором у перебігу інфекцій сечових шляхів.

Ключові слова: біоплівка, інфекція сечових шляхів, адгезія бактерій. 


\title{
СПОСОБНОСТЬ К ФОРМИРОВАНИЮ БИОПЛЕНОК, АДГЕЗИИ И ПОДВИЖНОСТИ У БАКТЕРИЙ, ВЫДЕЛЕННЫХ ОТ ДЕТЕЙ С ИНФЕКЦИЕЙ МОЧЕВЫХ ПУТЕЙ
}

\author{
Водяник А.А. ${ }^{1}$, Гречуха Е.А. ${ }^{1}$, Друзенко М.Г. ${ }^{1}$, Корнийко Е.Ю. ${ }^{1}$, \\ Понятовський В.А. ${ }^{1}$, Гнилоскуренко А.В. ${ }^{1}$, Лавренчук О.В. ${ }^{2}$, \\ Багдасарова И.В. ${ }^{2}$, Руденко А.В. ${ }^{3}$, Митюряева-Корнийко И.А. ${ }^{1}$,
}

${ }^{1}$ Национальный медицинский университет им. А.А. Богомольцуа, бул. Т. Шевченка, 17, Киев, 01601, Украина

${ }^{2}$ Институт нефрологии НАМН Украины, ул. Дегтяревская, 17-В, Киев, 04050, Украина ${ }^{3}$ Институт урологии НАМН Украины, ул. В.Винниченка, 9-А, Киев, 04053, Украина

\section{Резюме}

Целью данного исследования являлось определение интенсивности биопленкообразования, адгезивной способности бактерий и их подвижности в зависимости от разных видов инфекций мочевых путей у детей. Материалы и методы: в работе изучена способность к адгезии, подвижности и биопленкообразованию у 44 клинических изолятов бактерий, выделенных от детей, которые имели инфекцию нижних мочевых путей, острый и хронический пиелонефрит. Способность бактерий к формированию биопленок была проверена с помощью метода микротитровальных планшетов. Подвижность микроорганизмов исследовалась с помощью стандартных методов. Способность к адгезии была изучена по методике Брилиса с использованием формалинизированных эритроцитов. Результаты: были обнаружены отличия в способности формировать биопленку у штаммов бактерий, которые вызывают инфекцию нижних мочевых путей $(0,40 \pm 0,06$ ЕП) и хронический пиелонефрит $(0,48 \pm 0,07$ ЕП) $(\mathrm{p}<0,05)$. Также была установлена корреляция между адгезивной способностью бактерий и способностью к образованию биопленки $(\mathrm{r}=0,529(\mathrm{p}<0,01))$. Бактерии, способные к подвижности, имели сниженную способность к биопленкообразованию. Выводы: способность к адгезии и формированию биопленок выше у бактерий, которые были выделены у детей с хроническим пиелонефритом, в сравнении с бактериями, которые вызывали инфекции нижних мочевых путей. Высокая способность к формированию биопленок и адгезии у выделенных бактерий может считаться неблагоприятным прогностическим фактором в клиническом течении инфекций мочевых путей.

Ключевые слова: биопленка, инфекция мочевых путей, адгезия бактерий.

1. Romlingand U, Balsalobre C. Biofilm infections, their resilience to therapy and innovative treatment strategies. Journal of Internal Medicine. 2012; 272(6):541-61.

2. Centers for Disease Control and Prevention. Issues in Healthcare Settings: CDC's Seven Healthcare Safety Challenges. United States Department of Health and Human Services; Atlanta, GA, USA: 2001

3. Flores-Mireles AL, Walker JN, Caparon M, Hultgren SJ Urinary tract infections: epidemiology, mechanisms of infection and treatment options. NatRevMicrobiol. 2015;13(5):269-84.

4. Tenke P, Kovacs B, Jäckel M, Nagy E. The role of biofilm infection in urology. World Journal of Urology. 2006; 24(1):13-20. 
5. Nickel JC, Ruseska I, Wright JB, Costerton JW. Tobramycin resistance of Pseudomonas aeruginosa cells growing as a biofilm on urinary catheter material. Antimicrobial Agents and Chemotherapy. 1985; 27(4):619-24.

6. Anderson GG, Palermo JJ, Schilling JD, Roth R, Heuser J, Hultgren SJ Intracellular bacterial biofilm-like pods urinary tract infections. Science.2003; 301(5629):105-07.

7. Mulvey MA, Lopez-Boado YS, Wilson CL. et al. Induction and evasion of host defenses by type 1-piliated uropathogenic Escherichia coli. Science. 1998; 282(5393):1494-97.

8. Schwartz DJ, Chen SL, Hultgren SJ, Seed PC. Population dynamics and niche distribution of uropathogenic Escherichia coli during acute and chronic urinary tract infection. Infection and Immunity. 2011. 79(10):4250-59.

9. Robino L, Scavone P, Araujo L, Algorta G, Zunino P, Vignoli R. Detection of intracellular bacterial communities in a child with Escherichia coli recurrent urinary tract infections. Pathogens and Disease. 2013; 68(3):78-81.

10. Lane MC, Lockatell V, Monterosso G, Lamphier D, Weinert J, Hebel J.R, et al. Role of motility in the colonization of uropathogenic Escherichia coli in the urinary tract. Infection and Immunity. 2005; 73(11):7644-56.

11. Vollmerhausen TL, Katouli M. Molecular characterization of Escherichia coli isolated from hospitalised children and adults with urinary tract infection. Eur J Clin Microbiol Infect Dis. 2014; 33(6):975-82.

12. Merritt J, Cadouri DE, O’Toole GA. Growing and Analyzing Static Biofilms .Curr Protoc in Microbiol. Author manuscript.2005 Jul; 0 1: Unit-1B.1.

13. Brilis VI, Brilene TA, Lenzner HP. Metodika izuchenia adhesivnoho procesa microorganizmov.Lab.delo. 1986;(4): 210-12.Russian.

14. Eric Déziel, Yves Comeau, Richard Villemur. Initiation of biofilm formation by Pseudomonas aeruginosa 57RP correlates with emergence of hyper piliated and highly adherent phenotypic variants deficient in swimming, swarming, and twitching motilities. Journal of Bacteriology.2001; 183(4):1195-1204.

15. Tapiainen T, Hanni AM, Salo J, Ikäheimo I, Uhari M. Escherichia coli biofilm formation and recurrences of urinary tract infections in children.Eur J ClinMicrobiol Infect Dis. 2014; 33(1):111-15.

16. Hall-Stoodley L, Stoodley P. Developmental regulation of microbial biofilms. Curr Opin Biotechnol. 2002 Jun;13(3):228-33.

Отримано 4.04.2017 